\title{
Improving Disability Care in Countries of the Bolivarian Alliance for the Peoples of Our America
}

\author{
Miriam Portuondo-Sao MD PhD, Marcia Cobas-Ruiz PhD, Eduardo Zacca-Peña MD PhD, Araceli Lantigua-Cruz MD PhD, \\ Josefina López-García, Yosnel Boligán-Jomarrón MS, Martiza Leyva-Serrano MD MS, Anorys Herrera-Armenteros MD MS, \\ lleana R. Morales-Suárez MD MS
}

\begin{abstract}
Persons with disabilities constitute one of the most vulnerable groups in every society; their identification, assessment and care present a major challenge. In 2001-2003, Cuba conducted the first comprehensive national study of persons with disabilities in the Americas. In 2007-2010, the study was replicated in Bolivia, Ecuador, Nicaragua, Saint Vincent and the Grenadines, and Venezuela, at their governments' request. Study results have enabled implementation of strategies with substancial impact on human health in these countries. In response to it, more than a million medical consultations were provided by professionals whose specialties are lacking in the partici-
\end{abstract}

pating countries, including 139,772 clinical genetic consultations. Once each country's needs were identified, Cuba provided technical assistance with equipment supplied by Venezuela. The study led to development of public policies and programs for disability prevention and care of disabled persons in Bolivia, Ecuador, Nicaragua and Venezuela, and the opening of the National Medical Genetics Center and orthotic and prosthetic laboratories in Venezuela, and rehabilitation centers in Bolivia.

KEYWORDS Disability, epidemiology, health services research, needs assessment, human resources, workforce, Bolivia, Cuba, Ecuador, Nicaragua, Saint Vincent and the Grenadines, Venezuela

\section{INTRODUCTION}

WHO defines disability as "a complex condition of the human being consisting of biopsychosocial factors, which manifests itself through the reduction or temporary or permanent elimination of some type of ability, impeding a person's active participation in family and social activities without necessarily implying a complete incapacity or inability for social integration."[1]

Population studies of disability are scarce, due to its complexity as a health problem and its insufficient visibility, with subsequent lack of reliable and properly stratified data and outdated estimates of disability burden.[2-4] According to WHO, more than a billion people worldwide have some sort of disability, and between 110 and 190 million adults have serious functional limitations.[5] The World Report on Disability 2011 estimated some 190 million people (3.8\% prevalence) with a serious disability (associated with conditions such as quadriplegia, severe depression or blindness).[6]

Bolivarian Alliance for the Peoples of Our America (ALBA) is an 11-country trade and cooperation association in Latiun America and the Caribbean. For ALBA countries, disability is a major social and health problem that needs both accurate statistics and adequate social policies to solve or mitigate its main accompanying problems.[7] Several ALBA countries governments requested replication of the first comprehensive national study of persons with disabilities in the Americas (carried out in Cuba in 2001-2003).

The resulting field research conducted between 2007 and 2010 among persons with disabilities in Bolivia, Ecuador, Nicaragua, Saint Vincent and the Grenadines, and Venezuela has enabled identification of steps needed to address the problem at social, educational and health care levels. Each country mobilized the resources to develop the study and undertake subsequent actions in response to its findings. An action research approach was taken, beginning with study of people with disabilities and allowing for continuation of short-term actions and gradual development of other medium- and long-term strategies. Study methods and results from the research phase have been published elsewhere.[7]

\section{INTERVENTION}

Persons with any type of disability—whether visual, auditory, motor or cognitive-may have specific needs for assistance to attenuate their disadvantages with respect to the rest of society. The ALBA study therefore also included a census of the most urgent needs: adjustable beds for home care, antidecubitus mattresses, various types of wheelchairs, bathing chairs, walkers, crutches, canes, glasses, prosthetics, and hearing aids, etc. It also identified educational needs and needs for specialized medical care.[7] In each country, a team of local and Cuban specialists in the areas of health care, labor, education and social work, among others, was created to assess the different cases. The teams decided which resources should be provided, and established priorities according to the urgency, severity and magnitude of problems encountered in each country.

The information obtained also served as input to the design and implementation (with the participation of Cuban specialists) of policies, programs and strategies specific to particular situations encountered and their corresponding priorities. These programs were launched beginning in 2009 , and the process continued as studies were completed in successive countries. In July 2015 , a summative evaluation of their results was carried out, outlined below.

\section{RESULTS AND LESSONS LEARNED}

The results of the ALBA study ratified the usefulness of SouthSouth cooperation to identify and address disability needs, offering services whose costs would otherwise have been prohibitive for both the countries and patients involved. Another important result was development and validation of a Cuban method for biopsychosocial study of persons with disabilities, using the clinical method as the prime tool for identifying causes of disability.[8,9] The method was employed in clinical genetic, neuropediatric, 
Table 1: Number of persons with disabilities and percentage by type in six ALBA countries, and patient consultation

\begin{tabular}{|c|c|c|c|c|c|c|c|}
\hline Variables & $\begin{array}{l}\text { Cuba }^{a} \\
\text { n (\%) }\end{array}$ & $\begin{array}{c}\text { Venezuela } \\
\text { n }(\%)\end{array}$ & $\begin{array}{l}\text { Ecuador } \\
\text { n (\%) }\end{array}$ & $\begin{array}{l}\text { Nicaraguad } \\
n(\%)\end{array}$ & $\begin{array}{l}\text { Bolivia }^{e} \\
\text { n (\%) }\end{array}$ & $\begin{array}{c}\text { Saint Vincent } \\
\text { and the Grenadines } \\
\text { n (\%) }\end{array}$ & Total \\
\hline Persons with disabilities & 366,864 & 338,545 & 293,743 & 126,316 & 82,087 & 2195 & $1,207,472$ \\
\hline Cognitive disabilities & $\begin{array}{l}140,489 \\
(38.3 \%)\end{array}$ & $\begin{array}{l}100,124 \\
(29.6 \%)\end{array}$ & $\begin{array}{r}71,417 \\
(24.3 \%)\end{array}$ & $\begin{array}{r}32,741 \\
(25.9 \%)\end{array}$ & $\begin{array}{r}18,429 \\
(22.5 \%)\end{array}$ & $\begin{array}{r}497 \\
(22.6 \%)\end{array}$ & $\begin{array}{l}363,191 \\
(30.1 \%)\end{array}$ \\
\hline Other disabilities & $\begin{array}{l}226,375 \\
(61.7 \%)\end{array}$ & $\begin{array}{l}238,421 \\
(70.4 \%)\end{array}$ & $\begin{array}{l}222,326 \\
(75.7 \%)\end{array}$ & $\begin{array}{r}93,575 \\
(74.1 \%)\end{array}$ & $\begin{array}{r}63,658 \\
(77.5 \%)\end{array}$ & $\begin{array}{r}1698 \\
(77.4 \%)\end{array}$ & $\begin{array}{l}844,281 \\
(69.9 \%)\end{array}$ \\
\hline Genetic consultations & - & 38,972 & 21,062 & 27,134 & 10,231 & 489 & 139,772 \\
\hline Other specialty consultations & - & 15,676 & 35,257 & 37,063 & 15,874 & 231 & 104,101 \\
\hline $\begin{array}{l}\text { Consultations with other (nondisabled) } \\
\text { persons in the community }\end{array}$ & - & 605,395 & 825,576 & 203,457 & 326,256 & 7009 & $1,967,693$ \\
\hline
\end{tabular}

ALBA: Bolivarian Alliance for the Peoples of Our America

${ }^{a}$ data collected 2001-03 ${ }^{b}$ data collected 2007-08 ${ }^{c}$ data collected 2010 data collected 2009-10 edata collected 2009-10 fdata collected 2010

neurophysiological, otorrhinolaryngological and psychological consultations. There were 139,772 clinical genetic consultations and 104,101 in the other four specialties. Distribution by country and type of disability is shown in Table 1.

The research also highlighted a serious lack of local specialized human resources for disability care. In Nicaragua, for example, the only available specialty was clinical genetics; there were no specialists or doctors with postgraduate training for followup of patients after identifying the causes of their disability. To compensate for this deficit, another action consisted of Cuba training specialists and technicians in various genetics subspecialties, including clinical genetics, genetic counseling and laboratory cytogenetics. This included:

- training of four clinical geneticists from Venezuela in Cuba (They returned to Venezuela in 2013 to take up duties in Venezuela's Ministry of Public Health);

- training in Cuba of six cytogeneticists and three laboratory technicians for Venezuela's National Medical Genetics Center (developed with Cuban technical assistance);

- in 2011, graduation of Venezuela's first master of genetic counseling class of six family physicians;

- in 2011, launch of the first master of genetic counseling program for ALBA countries (offered at Cuba's National Medical Genetics Center), comprising 36 doctors: 18 from Venezuela, 9 from Bolivia and 9 from Nicaragua (They all graduated in 2013, returning to provide disability care in their respective countries);

- in 2011, two Nicaraguans and one Bolivian beginning residency training in clinical genetics (The three finished in 2015, returning to work in their respective national programs);

- in 2012, incorporation of four Ecuadorian doctors in the clinical genetics residency and six in the master of genetic counseling program at Cuba's National Medical Genetics Center (They all graduated and returned to work in Ecuador's Ministry of Health); and

- in March 2015, incorporation of 23 new specialists in Venezuela's master of genetic counseling program (The program follows the same curriculum used in Cuba, and is offered full time in Venezuela by Cuban faculty).

As of the 2015 evaluation, 68 professionals and technicians in ALBA countries had been trained in genetics, and 28 others were in training.

The study also identified a lack of public orthotic and prosthetic services in the countries studied, to which Cuba responded by offering its expertise in construction and establishment of facilities for manufacturing orthotics and prosthetics, to enable provision of such devices free of cost. These were developed based on needs identified in each country. In Venezuela, on-site training of orthotic and prosthetic technicians under supervision of Cuban specialists and following the Cuban curriculum enabled establishment of 11 orthotic and prosthetic laboratories (staffed by Cubans and Venezuelans), located in the Capital District (3), Lara (2), and 1 in each of Mérida, Anzoátegui, Zulia, Carabobo, Miranda and Nueva Esparta. Another laboratory in the state of Sucre was in its final stages of completion as of September 2015. The abovementioned laboratories employ 81 Venezuelan high school graduates with training in orthotics and prosthetics, supervised by 20 Cuban university graduates in the field.

Four more laboratories are planned for the states of Vargas, Barinas, Bolívar and Apure, where the legal process of acquiring real estate and equipment is under way. The country will have 16 in total, offering free services to Venezuelans. These centers have provided more than 28,829 services throughout Venezuela, and have manufactured 10,286 devices, most frequently orthotics and lower-limb prosthetics, of great value, increasing functional autonomy of persons with physical motor disabilities. All of these laboratories provide free and inclusive service to the Venezuelan population.

In Bolivia, the study identified a need to train rehabilitation specialists, particularly for people in mountainous, desert and Amazon regions where persons with physical motor disabilities have difficulty accessing services. As of the time of evaluation, 17 rehabilitation centers had been opened in 6 of the country's 9 provinces, under the guidance of Cuban specialists and staffed by 65 certified Bolivian physiatrists and rehabilitation specialists trained by Cuban professors. Specialized nonmedical training in physical therapy and rehabilitation is expected to start in 2016 under the direction of Cuban and Bolivian professors, using the specialty program already developed in Bolivia by Cuban experts.

In Venezuela, professional and technical training for disability care builds on the Barrio Adentro program, begun in 2003, offering comprehensive primary care throughout the country, and a new medical education model, the Community Family Medicine Program.[14-17] 
Table 2: Distribution of Cuban-trained personnel for ALBA countries, by specialty

\begin{tabular}{|l|r|r|r|r|r|} 
Role & $\begin{array}{c}\text { Venezuela } \\
\mathbf{n}\end{array}$ & $\begin{array}{c}\text { Ecuador } \\
\mathbf{n}\end{array}$ & $\begin{array}{r}\text { Nicaragua } \\
\mathbf{n}\end{array}$ & $\begin{array}{c}\text { Bolivia } \\
\mathbf{n}\end{array}$ & Total \\
\hline $\begin{array}{l}\text { Genetic counselor } \\
\text { (with master's degree) }\end{array}$ & 24 & 6 & 9 & 9 & 48 \\
\hline Clinical geneticist & 4 & 4 & 2 & 1 & 11 \\
\hline Cytogenetics laboratory technician & 9 & - & - & - & 9 \\
\hline Orthotic and prosthetic technician & 81 & - & - & - & 81 \\
\hline Certified rehabilitation specialist & - & - & - & 65 & 65 \\
\hline Total & 118 & 10 & 11 & 75 & 214 \\
\hline
\end{tabular}

ALBA: Bolivarian Alliance for the Peoples of Our America

Table 2 shows the distribution of human resources-previously absent or very scarce-in ALBA countries resulting from workforce training delivered in response to study findings. In this South-South collaboration, Cuba contributed specialized services and training, and Venezuela provided logistical support, and sent 12,834 pieces of equipment and devices to Bolivia and more than 20,000 to Ecuador; 50 hearing aids were sent to Saint Vincent and the Grenadines.

The study provided information on the burden of disability and its causes, and led to development of social action programs, satisfying its objectives of producing knowledge while generating social improvements.[10] Among related studies on the topic we reviewed, none included active screening with analysis of a large number of variables, or immediate intervention in the community.[11-13] Another important lesson learned is the crucial role of action research in consolidating Cuba's support for programs for disability prevention and care for persons, made possible by developing a network of 214 trained country specialists who work closely together to care for persons with disabilities in Bolivia, Ecuador, Nicaragua and Venezuela. - $1 /$ -

\section{REFERENCES}

1. World Health Organization. Discapacidad y salud. Nota descriptiva $N^{\circ} 352$ [Internet]. Geneva: World Health Organization; 2015 Dec [cited 2016 May 12]. Available from: http://www.who.int/mediacentre/factsheets/fs352/es/. Spanish.

2. Hernández E. Capacidad de trabajo intelectual. In: Métodos, técnicas y enfoques en la atención psicológica. Havana: Editorial Ciencias Médicas 2011. Chapter 2, Propuesta de un sistema para la evaluación psicológica. Spanish.

3. Inter-American Development Bank [Internet] Washington, D.C.: Inter-American Bank; c2016 [cited 2015 Jan 14]. Estadísticas sobre discapacidad en América Latina y el Caribe. Available from: http://www.iadb.org/sds/SOC/site_6190_e .html. Spanish.

4. United Nations [Internet]. New York: United Nations; c2016. ENABLE Convention. Los derechos y la dignidad de las personas con discapacidad; [cited 2015 Jan 12]; [about 12 pages]. Available from: http://www.un .org/spanish/disabilities/default.asp?navid $=24 \&$ pid $=787$. Spanish .

5. World Health Organization [Internet]. Geneva World Health Organization; c2016. Fact File. 10 Facts on Disability; [cited 2016 Jun 24]. Available from: http://www.who.int/features/factfiles/ disability/facts/en/

6. World Health Organization. Informe Mundial de la Discapacidad [Internet]. Geneva: World Health Organization; 2011 [cited 2016 Jan]. 27 p. Available from: http://www.who.int/disabilities/ world_report/2011/accessible_es.pdf. Spanish.

7. Cobas Ruiz M, Zacca Pena E, Portuondo Sao M, Icart Pereira E, Jordán Hernández A, Gámez Fonseca M. La investigación-acción en la atención de personas con discapacidad en países del ALBA. Rev Cubana Genet Comunit. 2011;5(2-3):20-31. Spanish.

8. Cobas Ruiz M. La investigación-acción en la atención de las personas con discapacidad en las Repúblicas de Cuba y Bolivariana de Venezuela [thesis] [Internet]. [Havana]: National School of Public Health (CU); 2011 [cited 2016 Jan 10]. Available from: https:// core.ac.uk/display/11816384/tab/similar -list. Spanish.

9. Portuondo Sao M. Enfoque clínico-genético de la discapacidad intelectual en tres municipios de La Habana [thesis] [Internet]. [Havana]: University of Medical Sciences of Havana; 2012 [cited 2016 Jan 10]. Available from: http://tesis.repo. sld.cu/518/. Spanish.
10. Vidal Ledo M, Rivera Michelena N. Investigación-acción. Educ Méd Super. 2007;21(4). Spanish.

11. Sarabia Sánchez A, Egea García C. Epidemiología de la discapacidad en Gran Bretaña. Artículos y Notas [Internet]. 2001 Nov [cited 2016 Jan 12];5-23. Available from: http://usuarios .discapnet.es/disweb2000/art/EpiDisGB.pdf. Spanish.

12. Castillo Arenal T. Discapacidad, pobreza y objetivos del milenio. eldiariomontanes.es [Internet] 2007 Dec 3 [cited 2016 Jan 12]; [about 2 pages] Available from: http://www.eldiariomontanes.es/ prensa/2007. Spanish.

13. Vázquez A. La discapacidad en América Latina [Internet]. Washington, D.C: Pan American Health Organization; [cited 2016 Jan 11]. Available from: http://www.paho.org/Spanish/DD/ PUB/Discapacidad-SPA.pdf. Spanish

14. Pan American Health Organization. Plan Estratégico Social, MSDS, Agosto 2002. Origen y evolución de la Salud Pública en Venezuela. Caracas: Pan American Health Organization; 2003. p.13. Spanish.

15. Alemañy Pérez EJ, Otero Iglesias J, Borroto Cruz $\mathrm{R}$, Díaz-Perera Fernández GM. Documentos rectores del proceso de formación y el modelo de Especialista en Medicina General Integral. Educ Med Super. 2002;16(2):164-83. Spanish.

16. Leyva Delgado L, Santoya Labrada M, Quevedo Freites G, Barreto Lacaba RM, Alonso Jiménez Y. La Universidad Barrio Adentro. Un nuevo paradigma en la formación del recurso humano en Medicina Integral Comunitaria. Estado de Trujillo, 2005-2006. Educ Med Super [Internet] 2007 [cited 2016 Jan 11];21(3). Available from: http://www.imbiomed.com.mx/1/1/articulos.php ? method=showDetail\&id articulo $=52511 \&$ id _seccion $=570 \& i d \_$ejemplar $=5319 \& i d$ revista $=61$. Spanish

17. Valladares Marrero MA, Morales Suárez IR Hernández García L. Caracterización de desarrollo profesional de los médicos docentes durante la misión en Venezuela. Educ Med Super [Internet]. 2011 Oct-Dec [cited 2016 Jan 11];25(4):451-65. Available from: http://scielo.sld .cu/scielo.php?script=sci_arttext\&pid=S0864 $-21412011000400007 \&$ Ing $=$ es. Spanish

\section{THE AUTHORS}

Miriam Portuondo-Sao (Corresponding author: mpsao@infomed.sld.cu), clinical geneticist with a doctorate in medical sciences, Ministry of Public Health (MINSAP), Havana, Cuba

Marcia Cobas-Ruiz, social scientist with a doctorate in health sciences, Vice-Minister, MINSAP, Havana, Cuba.

Eduardo Zacca-Peña, physician-epidemiologist and health administrator with a master's degree and doctorate in medical sciences. Advisor, National Medical Records and Health Statistics Bureau, MINSAP, Havana, Cuba.

Araceli Lantigua-Cruz, clinical geneticist with a doctorate in medical sciences. Full professor and senior researcher, advisor, National Medical Genetics Center, Havana, Cuba.

Josefina López-García, psychologist. Coordinator, Dr. José Gregorio Hernández Mission for Disability Care, Caracas, Venezuela.

Yosnel Boligán-Jomarrón, rehabilitation specialist with a master's degree in public health. Coordinator, Moto Méndez Mission for Disability Care, La Paz, Bolivia.

Martiza Leyva-Serrano, physician specializing in physical medicine and rehabilitation with a master's degree in cardiopulmonary resuscitation. Head, Rehabilitation Department, MINSAP, Havana, Cuba.

Anorys Herrera-Armenteros, physician with a master's degree in genetic counseling. Deputy Director, Artemisa Provincial Genetics Center, Cuba.

Ileana R. Morales-Suárez, physician specializing in human anatomy, with a master's degree medical education. National Director for Science and Technology, MINSAP, Havana, Cuba.

Submitted: September 2, 2015

Approved for publication: June 16, 2016 Disclosures: None 